\title{
IMMUNOLOGICAL EFFECTS OF SOME ANTIGENS AND DNA SYNTHETIC RESPONSE ON MALE RABBITS.
}

\author{
M. H. El-Nenaey \\ Animal Production Research Institute, Dokki, Giza, Egypt.
}

\begin{abstract}
Seventy-two Californian male rabbits (CL) were randomly selected at 5.5 months old. They were divided into for equal four groups (18 rabbits each) according to results of immunization which they immunized four immunizations by four antigens: sheep red blood cells ( SRBCs ), bovine serum albumin ( BSA ), Rabbit gamma globulin $(R g G$ ), and phospho. L.tyrosine, (ph.L.ty), for group 1,2,3and 4, respectively. Each group was injected four immunizations with its antigen and with adjuvant : first was antigen with Freund's complete $(F C)$, the second was antigen with incomplete (FI), the third was antigen with flourscein isothio cyanate (FITC) conjugated to human serum albumin ( HAS ) and the last immunization with 5- iodo-2deoxyuridine ( I125 UDR). Rabbits were injected subcauteneously in first immunization, after 28 days the second immunization was intravenously. Also, 28 days later all rabbits groups were injected the third immunization in foot pad, after 15 days from the third immunization all rabbits were injected intravenously with the last immunization. Blood samples were taken from marginal ear vein intervals, 7, 14, 21-day post-first and second immunization to determine the serological tests (antibody assay and titration) and rabbits were classified later into high $(H R)$ and low response (LR) responded groups as a result of immune response. The low responder rabbits were culled of the experiment. At the end of experiment rabbits were sacrificed and blood samples were taken to estimate physiological and immunological traits. Also, semen characteristics and DNA synthesis of thymocyte tissues, PCR-DNA amplification with specific primer was carried out to study sequence of IgH thymocytes. The results of serological traits showed that there were significant differences ( $p<0.05)$ among rabbit groups, group (1) had superiority antibodies responses values and the lowest value was group (4).
\end{abstract}


Physiological parameters studied (TP, Alb, glo and A/G ratio) showed that there were significant differences ( $p<0.05$ ) among rabbit groups , group (3) had higher values and the lowest was group (1). Results of immunological traits: I (TWBCs and its differentiation, and total immunoglobulins (Ig) and its fractions Alpha immunoglobulin (IgA), Meu immunoglobulin (IgM) and Gamma (IgG) $\}$ showed that TWBCs and its differentiation were highly significant differences ( $p<0.01)$ among rabbit groups, group (1) and (3) had superiority values of (TWBCs) and its differentiation counts. The results of Ig were: group (3) had higher value of total Ig followed by group (4), but group (1) had lower value of Ig, whenever group (2) had intermediate value and there was significant differences $(P<0.05)$ among rabbit groups. Concerning of Ig fractions (IgA, IgM and IgG), there were significant differences $(P<0.05)$ among rabbit groups the greatest value of IgA was detected in serum of group (4), but the lower value was for group (1). The highest value of IgM was in group (1). Group (3) had higher value of $\operatorname{Ig} G$ than other groups. Concerning of DNA amplification there differences between bands according to the effect of different antigens and its stimulating to the IgH genes. Regarding semen characteristics there was a high significant differences $(p<0.01)$ among immunized rabbit groups, group (4) achieved the lowest value of dead and abnormal spermatozoa and the highest value of semen motility than other groups. It could be concluded that phospho - L.ty material had ability to stimulate DNA and induce immune response, besides increasing fertility of male rabbits.

\section{INTRODUCTION}

Studies in the rabbit have historically yielded now insight into a variety of aspects of the genetics, development and functions of the immune system.

Control of immunopoiesis has subjected of much investigation and a focus of recent genetic control studies of immunity. Also, numerous reports have demonstrated that the ability to produce antibody against a specific antigen can be influenced by one or few loci. This ability to 
respond has been studied in mice, rabbit and guinea pig by some investigators (Vaerman and Hermans. 1972, Biozzi et al., 1975, Helcio et al., 1977, Higgens and Gutrill 1984, Ferreira et al., 1986,Hirai et al., 1994, and Omara et al., 2002 ).

By using various natural or synthetic polypeptides antigens (e.g. bovine serum albumin, rabbit gamma globulin and sheep red blood cells) are nonpathogenic and induce antibody response.

In addition, the loci controlling the antibody have frequently been found to be closely linked to the Major Histocompatability (MHC) locus in a given species (Gottlieb et al., 1971).

Also, the differences in the magnitude of the response between low or non responders and high responders have been attributed either to defective recognition for the antigen, the $\mathrm{B}$ cell precursors specific for the antigen tested being present in equal numbers in responder rabbits or to differences in the frequency of immunocomptent precursors specific for the antigens tested.

Therefor, a level of genetic regulation of humoral immune responses has been observed in the structural gene central of the variable region of the antibody molecules and is independent of both the ability to synthesize immunoglobulin and the H.2 locus in mice (Perkins and Mukinodan, 1972).

In addition, there was a good correlation between the stimulatory capacity of the antigens and their antigenicity and some antigens have ability to DNA synthetic response of thymocytes and lead to thymus independency under experimental conditions (Particular antigen doses and the nature of "thymus - independancy " are necessary to understand the means by which $\mathrm{T}$ cells assist B cells in the production of antibodies (Kruger and Gershon, 1971). 
The aim of the present investigation was conducted to study the ability of certain antigens to stimulate DNA synthesis in thymocyes in rabbits and study the sequence of immunoglobulins heavy chain (IgH) genes by using PCR amplification to determine, the high fertility and immunity rabbits for using in breeding programs.

\section{MATERIALS AND METHODS}

This study was carried out in the rabbits farm in Sakha Research Station, Kafr EL-Sheikh Governorate, belonging to Animal Production Research Institute,Agricultural Research Center,Ministry of Agriculture. The fieldwork was started in September 2005 and terminated in March 2006.

\section{1- Experimental animals:}

A total of healthy seventy-two Californian rabbits (CL) males were used in this study, The average body weights males was $3150+130.0$.g. at 5.5 months old. Rabbits were divided into four groups (18 rabbits each). Rabbits groups were distributed according to the type of immunization with antigens which were: group 1(sheep red blood cells, SRBCs), group 2(Bovine serum albumin, BSA ), group 3( Rabbit gamma globulin, $\mathrm{RgG}$ ) and group 4 (phospho -L-tyrosine, ph.L.ty) respectively. Sheep red blood cells (SRBCs) were obtained in AL Selver's solution from sheep of Sakha Research farm and were washed six times with phosphate buffer saline (PBS) before use. Eech group was injected four immunizations using antigen and with adjuvant : first group was injected with antigen freund's incomplete (FI), the second group was injected antigen with freund's complete (FC), the third was injected with antigen and floursciene isothiocynate (FITC) conjugated to human serum albumin (HAS) fourth group was injected with antigen and 5-iodo-2deoxyuridine (I125 UDR). The dose was $(0.50 \mathrm{ml}$ antigen $+0.50 \mathrm{ml}$ $(\mathrm{PBS})+0.250 \mathrm{ml}$ carriers. 


\section{2- Feeding and Management:}

Experimental animals were housed and Kept separately in individual cages $(30 \times 30 \times 50 \mathrm{~cm})$ in a battery system provided with automatic nipples for drinking fresh water. Rabbits fed ad-libtum on commercial balanced pelted ration containing $17 \%$ crude protein, 12.91 crude fiber and 2.13 ether extract providing 2415 digestible energy (Kcal / Kg feed).

\section{3- Measurements and Technical procedures:}

Immunological, hematological, traits, semen characteristics and DNA synthesis of thymocytes and polymrease chain reaction (PCR) amplification were studied as follows:

Rabbits were injected subcauteneously in first immunization, after 28 days the second immunization was intravenously. Also, 28 days later all rabbits groups were injected the third immunization in foot pad, after 15 days from the third immunization all rabbits were injected intravenously the last immunization.

Blood samples were taken from marginal ear vein by needle syringe at time intervals, 7, 14, 21- day post -first and second immunization to determine the serological tests (antibody assay and titration) according to the methods of Shaker (1997): The immune sera were obtained through blood which separated by centrifugation at 3000 r.p.m for 10 minutes and pooled and complement inactivated by Keeping at 56 OC for 30 minutes to metabolism of some antigen - antibody complex inhabits according to the methods of walter and Zipper (1958) to study the blood parameters: total white blood cells (TWBCs) and its differentiation count by using white blood diluting pipette (Coffin, 1955 and Schalm 1965), total protein (TP) values were determined by the colorimeter methods according to Merk (1974), albumin was determined by calorimetric method of Doumas et al., (1971) and globulin was obtained by subtracting the value of albumin from the corresponding 
value of total protein. The individual serum antibody responses for rabbits groups were measured by passive haemagglutination reaction with rabbit's erythrocytes coupled with 4 antigens. The titration was in micro plates (micro titer $U$ plates) as follows: $0.250 \mathrm{ml}$ of doubling serum dilution in phosphate buffer saline (PBS) was added to $0.250 \mathrm{ml}$ of suspension containing 108 sensitized erythrocytes / $\mathrm{ml}$. The reaction was scored of the $24 \mathrm{hr}$ at room temperature.

The antibody titers (Abs ) expressed as $\log 2$ of the highest serum dilution giving positive agglutination. According to the results of titration test, all rabbits groups were divided into high and low antibody responses, the low antibody response rabbits were culled and all high antibody responder rabbits were kept under the present investigation.

Immunolcgical tests carried out, were Hemagglutination test response for antibodies from rabbit's serum against antigens was performed according to the method of Kabat and Mayer (1961). And, rabbit serum of total immunoglobulins ( $\mathrm{Ig}$ ) and its fractions ( $\operatorname{Ig} \mathrm{A}, \mathrm{IgG}$ and $\operatorname{IgM}$ ) were determined by using specific kits, and SDS-APGE polyacrylamide gel electrophoresis pattern of serum protein; According to Choi et al.,(1991).

At the end of the experiment rabbits were sacrificed and thymus gland spleen and bone marrow were removed, in addition, DNA synthesis of thymocytes was determined as follows: Cell suspension: thymocyte suspensions were made by gently squeezing minced thymuses between sterile glass slides in ice cold medium (M199). After two washes cells were counted by using trepan the trepan blue dye exclusion method. Bone marrow cell suspensions were made by flushing the femurs with ice cold medium and (M199) DNA synthesis of thymocytes was carried out accordions to the method of Kruger and Gershon, 1972). DNA extraction from blood before immunization and from thymocyte tissues and spleen glands were done. Also,DNA polymereas chain reaction were done using Kits and instruction of promega Company, as follows: 
1- DNA extraction by using Qia gen. Kit.

2- Spectrophotometer determination of DNA concentration.

3- PCR amplification carried out according to promega protocol with specific primer described by Candace et al., (1999) that used VHPr,5'TAACAACCTTAAAATTCATGATCTGAATC-3: UPVH - H3,5 'TCCAAGCTTATCACAGCCATCAC-3': and 3JHV .5'- GTAGGAGCTCGAGTTGGCAAGGA CTCAAC-

4- Agarose gel electrophoresis 1.5-\% concentration.

5- Photography using Polaroid camera and analysis by Gel Dro software. USA. Molecular weight marker lode 100 - 1500 bp ladder fran Bio Basic Inc., Canada.

Semen was collected using an artificial vagina technique and immediately evaluated after collection. Semen was collected from rabbits groups twice weekly throughout the experimental period before and after immunization to determine semen characteristics:volume,sperm motility, dead spermatozoa, sperm abnormalities and sperm concentration.

\section{4- Statistical analysis:}

Data were statistically analyzed according to SPSS program (SPSS for windows, computer program. 1993). Snedecor and Cochran (1967) percentage values were transformed to arcsine values before analyzed. Dancan's Multiple Range tests, (Duncan, 1955) was used for testing significance of the differences between the means.

\section{RESULTS AND DISCUSSION}

\section{1- Antibody assay and titration:}

Table (1) and Fig. (1 and 2) illustrated the effect of primary and secondary immunization against 4 antigens (SRBCs, BSA, RgG, and $\mathrm{Ph} . \mathrm{L}$.Ty) at 7,14 and 21-d post-immunization resulting high and low responder rabbit (the low responder rabbits were culled) and showed that 
means of antibody titers values were increased gradually after the primary injection and reached its maximum level at $7 \mathrm{~d}$ postimmunization, then decreased gradually to reach the lowest level at $21 \mathrm{~d}$ post -immunization for high response Californian rabbits males. SRBCs and $\mathrm{RgG}$ groups had higher antibodies value followed by BSA and the lowest was ph.L.Ty group.

These results were in agreement with the result reported by passos et al., (1977), Sant' Anna (1983), Ferreira et al., (1986), Wilkie and Malllard. (1999), Klipper et al., (2000), Fusheng et al., (2002) and Abou-Elewa (2004) they demonstrated that antibody immune responses were respect to the humoral immune response and cell mediated immunity (CMI) which the antigen stimulates differentiation of both $\mathrm{B}$ and $\mathrm{T}$ cells into plasma cells and memory cells. They explained the increasing of antibodies gradually reaches a peak by 6-7 d postimmunization, and then declines acceding to the capacity to develop a secondary antibody response depends on the existence and activation of a population of memory $\mathrm{B}$ and $\mathrm{T}$ cells. The differences of antibody responses for antigens immunization due to the differential ability of antigen to simulates B and T cells, whereas the SRBCs, had superiority antibodies responses and the lowest value was phospho. L.Tyrosine (Ph.L.Ty).

2- Physiological traits:

Least - squares means and standard errors of the physiological traits of Californian males rabbits as affected to SRBCs, BSA, RgG and ph.L.tyrosine antigens immunization are presented in Table (2) and Fig (3), they showed that there were a significant differences $(p<0.05)$ among rabbits groups in plasma total protein (TP), albumin (Alb), globulin (glo) and A/G ratio. The means of total protein and albumin had higher values in rabbits group immunized with rabbit gamma globulin

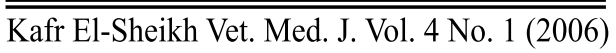


(RgG) and bovine serum albumin (BSA), followed by phospho. L.Tyrosine (Ph.L.Ty) and the lowest value was sheep red blood cells. Concerning of globulin, $\mathrm{RgG}$ and BSA groups had higher values followed by SRBCs group and the lowest value was Ph.L.Ty group. Concerning of A/G ratio, BSA and Ph.L.Ty groups had higher values followed by $\mathrm{RgG}$ group and the lowest value was SRBCs group. The superiority of these antigens than SRBCs due to their belonging to polypeptide chains, increasing of $\mathrm{A} / \mathrm{G}$ ratio lead to metabolic activities and its ability to regulate the requirements for cell activity (Grimminger ., 1986).

\section{3-Immunological traits:}

\section{3-1. Total white blood cells and its differences:}

The results of total white blood cells and its differentiation are presented in Table (3). There were highly significant differences $(\mathrm{p}<$ 0.01 ) among rabbits groups. SRBCs and $\mathrm{RgG}$ groups had higher values of total White blood cells (TWBCs) and its differentiation than ph.L.ty and BSA groups. The increasing (TWBCs) values and its differentiation resulted by antigen immunization due to being foreign molecules proteins, have polypeptide chain and their ability to associates with the peripheral blood leukocytes as lymph proliferation with increased of levels of neutrophils and monocytes indicated for these responder rabbit groups, whenever nentrophils eliminate the foreign materials via phagocytes and may increase their immune response (Helal and Mousa, 2005).

\section{3-2. Immunoglobulins parameters:}

Concerning of Immunoglobulins parameters:total immunoglobulins (Ig) and its fractions (IgA, $\operatorname{IgM}$ and $\operatorname{IgG}$ ) are listed in Table (4) and Fig. 
(4) ,besides Fig (7) for SDS - PAGE electrophoretic Patterns of protein analysis. There were significant differences $(p<0.05)$ among rabbit groups. The results of total immunoglobulins were: the rabbits group immunized with $\mathrm{RgG}$ had highest value of total Ig were $(915.357+0.147)$ followed by rabbits group immunized with ph.L -ty $(910 \pm 0.635)$, whenever the rabbits group immunized with SRBCs antigen had lowest Ig value $(730.00 \pm 0.854)$ but the rabbits group immunized with BSA antigen had intermediate value and there were significant differences $(\mathrm{P}<$ 0.05) among rabbit groups. Concerning of IgA there were significant differences $(\mathrm{P}<0.05)$ among immunized rabbits groups, the present results showed the lower value of $\operatorname{IgA}$ antibodies was detected in the serum of rabbit group immunized with SRBCs antigen, but the greatest value was rabbits group immunized with ph.L.ty antigen. Regarding IgM antibodies in serum of immunized rabbits, there were significant differences $(\mathrm{P}<0.05)$ among immunized rabbits groups, the highest value of $\operatorname{IgM}$ was in rabbits group immunized with SRBCs antigen than other groups. Also, gamma immunoglobulins (IgG) levels had higher significant differences $(\mathrm{p}<0.01)$ among immunized rabbit groups, which the greatest value was in $\mathrm{RgG}$ rabbits group (442.900+0.49), the lowest was immunized with SRBCs (158.950+0.020).

These results demonstrated that the increasing of immunoglobulins (Ig) in rabbits groups immunized with $\mathrm{RgG}$ antigen was indicator for response of immune system of rabbits groups as a result of some chemical, Toxi agents and foreign bodies as globulin antigens (Helal and Mousa 2005), are formed in reticuloendothelial tissue, in plasma cells and lymphocytes (Munro, 1970) which indicated that rabbits immunized with antigens using adjuvants in immunization increase the immune system. The present results were in harmony with Vaerman and Heremans, (1972) Rothberg and peri (1986), parmentier et al., (1994). They reported that divergent selection of antigen immunization maybe increase the $\mathrm{Ig}$ and $\mathrm{IgG}$ values. 
Ph.L.Ty might be useful due it has L. tyrosine which acts as a strong antioxidant either directly by radical trapping (Van Overveld et al, 2000) or being an inhibitor of lipid peroxidation due to its hydrophobic structure containing only one charged residue (Moosmen and Behi, 2002).

\section{4- DNA amplification:}

Fig (5) showed of rabbit's blood samples before immunization that hadn't any differentiation among bands were observed as compared to Fig (6) which showed positive samples from them when immunized with four considerable antigens, the nucleotide sequences of the identified $\mathrm{IgH}$ genes were detected by PCR and its products showed genetic differences among immunized rabbit groups and differential bands, whereas the molecular weight was measured by DNA marker (M) ranged from 100 1500 base pair (bp) it noticed that lane lane 2 ( L2 ) of SRBCs sample was faint and had low molecular weight reached to $180 \mathrm{bp}$ while, L8 achieved superiority of molecular weight for $\mathrm{RgG}$ band reached to 550 , and L10 for BSA was $440 \mathrm{bp}$ and very faint in L4 for ph.L-ty was 240 $\mathrm{bp}$, that maybe due to the effect of different antigens to stimulate the $\operatorname{IgH}$ genes loci and it proved depending upon the annealing of specific primer (used in the experiment) with PCR products

It demonstrated that SRBCs, BSA, RgG and ph. L- ty antigens had ability to stimulate capacity of DNA . Furthermore, phospho.L.tyrosin achieved highest value of molecular weight than others, maybe due to that heavy chains from phosphoric form binding proteins, all anti phosphoric antibodies have five differences and ability for sbstituations of four loci in the framework portion of $\operatorname{IgH}$ of variable region (Rudikoff and Potter, 1980). 


\section{5-Semen characteristics:}

Table (5) showed that rabbits group immunized with ph.L.ty achieved superiority values of semen quality than the other immunized groups, which had higher value of semen motility was $41.33+4.03$ as compared to control group ( rabbit groups before immunization ) was $38.30+4.05$ and immunized rabbit groups was $21.36+3.71,20.67+$ 2.91 and $13.67+2.25$ for BSA, RgG and SRBCs, respectively. Besides, those immunized rabbits group with ph.1.TY had the lowest value of dead and abnormal spermatozoa as compared to immunized rabbits groups with SRBCs, BSA, RgG and control group. That may be due to the L.tyrosine acts as strong antioxidant. Peroxidation has been considered as one of the major causes of infertility (Jones et al., 1979) and the important role of phospho - L.ty to increase GNRh and prostate gland.

It demonstrated that rabbits group immunized with ph.L.ty the lowest effect of antigen reaction than other rabbits group due to antibodies to those antigens reactions and inhibit gamete function and comprise fertilization (Nas, 1996) but, ph.L.ty immunization due to has L.tyrosine (besides phosphorous), is a semi essential amino acid and play an important role in formation of thyroid hormones (T3 and T4) and stimulating GNRh because the availability influences synthesis of norepinephrine (Wartman., 1982) and involved indirectly in the transmission of the stimulatory effect of progesterone on the release of LH and FSH via receptor mechanism (Pushpa et al., 1972) and acts as a strong antioxidant (Vnoverveld et al. , 2000).

It could be concluded that ph. L-ty chemical material can use successfully in meal rabbits induces immune response, fertilized material and is bribe of DNA synthesis to determine which meal rabbits have both high immune response and fertility. And, suggest that needs further more work. 
2- Immunological Effects Of Some Antigens And Dna Synthetic ...

Table (1): Means of primary and secondary of antibody titers against to SRBCs, BSA, RgG and ph.L.ty at 7.14 and $21 \mathrm{~d}$ post immunization for high. Immune response Californian rabbits.

\begin{tabular}{|c|c|c|c|c|c|c|c|}
\hline \multirow{2}{*}{ Groups } & \multirow{2}{*}{$\begin{array}{l}\text { No. of } \\
\text { rabbits }\end{array}$} & \multicolumn{3}{|c|}{ Primary Ab titer. } & \multicolumn{3}{|c|}{ Secondary Ab titer. } \\
\hline & & 7 & 14 & 21 & 7 & 14 & 21 \\
\hline SRBCs & 10 & 6.42 & 3.20 & 1.20 & 9.83 & 6.41 & 1.40 \\
\hline BSA & 10 & 5.81 & 1.20 & 0.70 & 6.0 & 2.8 & 1.20 \\
\hline $\mathrm{RgG}$ & 10 & 6.25 & 2.40 & 1.20 & 9.50 & 6.25 & 1.30 \\
\hline Ph.L.ty & 10 & 2.40 & 1.20 & 0.60 & 5.61 & 2.23 & 1.20 \\
\hline
\end{tabular}

SRBCs $=$ Sheep red blood cells.

BSA $=$ Bovine serum globulin.

$\mathrm{RgG}=$ Rabbit gamma globulin .

Ph.L.ty $=$ Phosph.L. tyrosine.

$\mathrm{Ab} \quad=$ Antibody titer.

Table (2): Least - squares means (LSM \pm SE) of physiological traits of Californian rabbits serum as affected to SRBCs, BSA , RgG, and Ph.L.ty immunization.

\begin{tabular}{|c||c|c|c|c|}
\hline \multicolumn{1}{|c||}{} & \multicolumn{4}{c|}{$($ LSM \pm SE) Groups } \\
\cline { 2 - 5 } Items & SRBCs & BSA & RgG & Ph.L.ty \\
\hline \hline $\mathrm{TP}(\mathrm{g} / \mathrm{dI})$ & $4.650 \pm 0.083^{\mathrm{a}}$ & $7.500 \pm 0.063^{\mathrm{b}}$ & $7.850 \pm 0.066^{\mathrm{b}}$ & $6.560 \pm 0.327^{\mathrm{ab}}$ \\
\cline { 2 - 5 } & $1.260 \pm 0.0233^{\mathrm{a}}$ & $4.089 \pm 0.048^{\mathrm{c}}$ & $3.930 \pm 0.0722^{\mathrm{b}}$ & $3.170 \pm 0.929^{\mathrm{b}}$ \\
\hline $\mathrm{AIb}(\mathrm{g} / \mathrm{dI})$ & $3.390 \pm 0.0 .059^{\mathrm{a}}$ & $3.461 \pm 0.138^{\mathrm{a}}$ & $4.20 \pm 0.059^{\mathrm{b}}$ & $3.170 \pm 0.134^{\mathrm{a}}$ \\
\hline $\mathrm{Glob}(\mathrm{g} / \mathrm{dI})$ & $0.371^{\mathrm{a}}$ & $1.19^{\mathrm{b}}$ & $0.94^{\mathrm{a}}$ & $1.000^{\mathrm{a}}$ \\
\hline $\mathrm{A} / \mathrm{G}$ ratio & & & & \\
\cline { 2 - 5 } & & &
\end{tabular}

A, b, and c values having different superscripts in the same row are high significant different at $(\mathrm{P}<0.05)$. 
Table (3): Least-squares means $(\mathrm{LSM}) \pm \mathrm{SE}$ ) of total white blood cells differentiation of Californian rabbit serum as affected to SRBCs, BSA , RgG and Ph.t immunization.

\begin{tabular}{||l||c|c|c|c||}
\hline \multicolumn{1}{|c||}{ Items } & \multicolumn{4}{c||}{ (LSM \pm SE) Groups } \\
\cline { 2 - 5 } & SRBCs & BSA & RgG & Ph.ty \\
\hline \hline TWBC $\left(10^{3} / \mathrm{mm}^{3}\right)$ & $12.400 \pm 0.012$ & $7.220 \pm 0.118^{\mathrm{b}}$ & $12.00 \pm 0.051$ & $6.850 \pm 0.356$ \\
\hline Monocyte $\left(10^{3} / \mathrm{mm}^{3}\right)$ & $1.4000 \pm 0.10^{\mathrm{b}}$ & $0.50 \pm 0.2007^{\mathrm{a}}$ & $1.50 \pm 0.089^{\mathrm{b}}$ & $0.70 \pm 0.1530^{\mathrm{a}}$ \\
\cline { 2 - 5 } & $6.50 \pm 0.058^{\mathrm{b}}$ & $4.4 \pm 0.535^{\mathrm{ab}}$ & $6.8 \pm 0.046^{\mathrm{b}}$ & $3.70 \pm 0.596^{\mathrm{a}}$ \\
\hline Lymphocyte $\left(10^{3} / \mathrm{mm}^{3}\right)$ & $5.90 \pm 0.069^{\mathrm{b}}$ & $3.40 \pm 0.378^{\mathrm{b}}$ & $3.60 \pm 0.012^{\mathrm{a}}$ & $3.90 \pm 0.301^{\mathrm{a}}$ \\
\hline Neutrophil $\left(10^{3} / \mathrm{mm}^{3}\right)$ & 5 & & &
\end{tabular}

A, b, and c values having different superscripts in the same row are significantly different at $(\mathrm{P}<0.05)$.

Table (4): Least - squares means (LSM) \pm SE of total immunoglobulins, IgA, $\operatorname{IgM}$ and IgG traits Californian rabbits serum as affected by SRBCs, RgG BSA and Ph.ty immunization.

\begin{tabular}{||c||c|c|c|c||}
\hline \multirow{2}{*}{\multicolumn{1}{|c|}{ Items }} & \multicolumn{4}{|c|}{ (LSM \pm SE) Groups } \\
\cline { 2 - 5 } & SRBCs & BSA & RgG & Ph.L-ty \\
\hline \hline Ig Total (mg/dI) & $730.000 \pm 0.854^{\mathrm{a}}$ & $799.337 \pm 0.053^{\mathrm{a}}$ & $915.357 \pm 0.149^{\mathrm{c}}$ & $910.050 \pm 0.635^{\mathrm{b}}$ \\
\cline { 2 - 5 } & $23.110 \pm 0.0640^{\mathrm{a}}$ & $20.190 \pm 0.605^{\mathrm{b}}$ & $19.100 \pm 0.605^{\mathrm{b}}$ & $18.800 \pm 0.233^{\mathrm{c}}$ \\
\hline $\operatorname{IgA}(\mathrm{mg} / \mathrm{dI}):$ & $533.150 \pm 0.383^{\mathrm{a}}$ & $435.980 \pm 0.035^{\mathrm{b}}$ & $439.149 \pm 0.869^{\mathrm{a}}$ & $436.070 \pm 0.086^{\mathrm{b}}$ \\
\hline $\operatorname{IgM}(\mathrm{mg} / \mathrm{dI}):$ & $158.950 \pm 0.020^{\mathrm{d}}$ & $323.570 \pm 0.049^{\mathrm{c}}$ & $442.900 \pm 0.049^{\mathrm{a}}$ & $433.8 \pm 0.050^{\mathrm{b}}$ \\
\hline $\operatorname{IgG}(\mathrm{mg} / \mathrm{dI}):$ & & & &
\end{tabular}

$\mathrm{a}, \mathrm{b}$ and $\mathrm{c}$ values having different superscripts in the same row are high significant different at $(\mathrm{P}<0.01)$. 
2- Immunological Effects Of Some Antigens And Dna Synthetic ...

Table(5):Semen characteristics of Californian rabbits males before immunized with SRBCs, BSA, RgG and Ph-L-Ty. antigens.

\begin{tabular}{|c|c|c|c|c|c|}
\hline Itens & Control & SRBC & BSA & RgG & Ph-L-Ty \\
\hline Volume (ml) & $0.49 \pm 3.97^{\mathrm{ab}}$ & $0.40 \pm 3.61^{\mathrm{a}}$ & $0.93 \pm 4.70^{\mathrm{ab}}$ & $0.44 \pm 4.76^{\mathrm{ab}}$ & $0.83 \pm 0.26^{\mathrm{b}}$ \\
\hline $\begin{array}{c}\text { Sperm motility } \\
\%\end{array}$ & $38.33 \pm 4.65^{\mathrm{b}}$ & $13.67 \pm 2.25^{\mathrm{a}}$ & $21.36 \pm 3.71^{\mathrm{a}}$ & $20.67 \pm 2.91^{a}$ & $41.33 \pm 4.03^{\mathrm{b}}$ \\
\hline $\begin{array}{c}\text { Dead } \\
\text { spermatozoa } \%\end{array}$ & $15.83 \pm 2.23^{\mathrm{b}}$ & $20.67 \pm 1.92^{\mathrm{bc}}$ & $25.79 \pm 3.00^{\mathrm{c}}$ & $24.87 \pm 2.76^{c}$ & $15.13 \pm 2.50^{\mathrm{b}}$ \\
\hline $\begin{array}{c}\text { Sperm } \\
\text { abnormal \% }\end{array}$ & $17.23 \pm 1.99^{\mathrm{a}}$ & $53.10 \pm 1.69^{\mathrm{c}}$ & $46.02 \pm 2.31^{\mathrm{b}}$ & $44.02 \pm 2.64^{\mathrm{b}}$ & $17.63 \pm 1.32^{\mathrm{a}}$ \\
\hline $\begin{array}{c}\text { Sperm } \\
\text { concentration }\end{array}$ & $402.67+31.34^{\mathrm{ab}}$ & $261.00+22.35^{\mathrm{cc}}$ & $330.00+19.50^{\mathrm{bc}}$ & $335.00+15.98^{\mathrm{bc}}$ & $205.62+29.17^{\mathrm{a}}$ \\
\hline
\end{tabular}

A , b, and c values having different superscripts in the same row are different significant at $(\mathrm{P}<0.05)$.

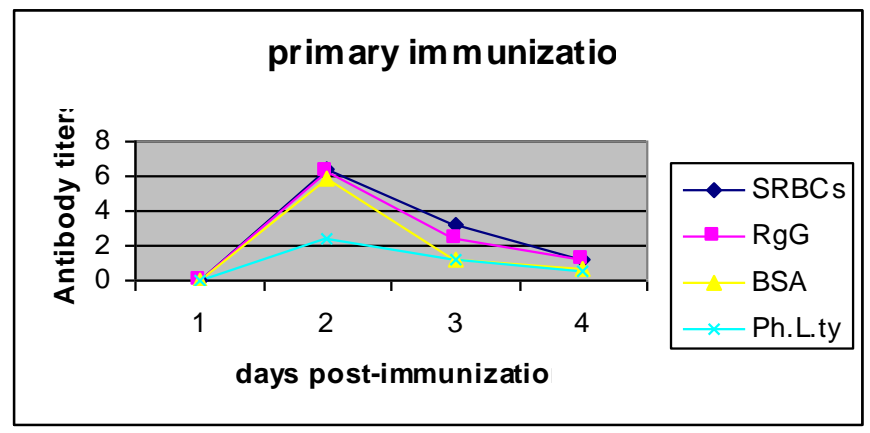

Fig. (1): primary antibody response for antigens

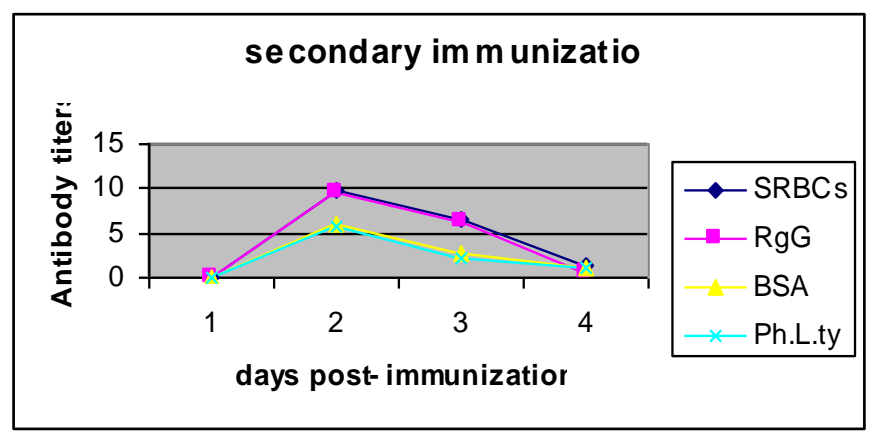

Fig. (2): secondary antibody response for antigens 

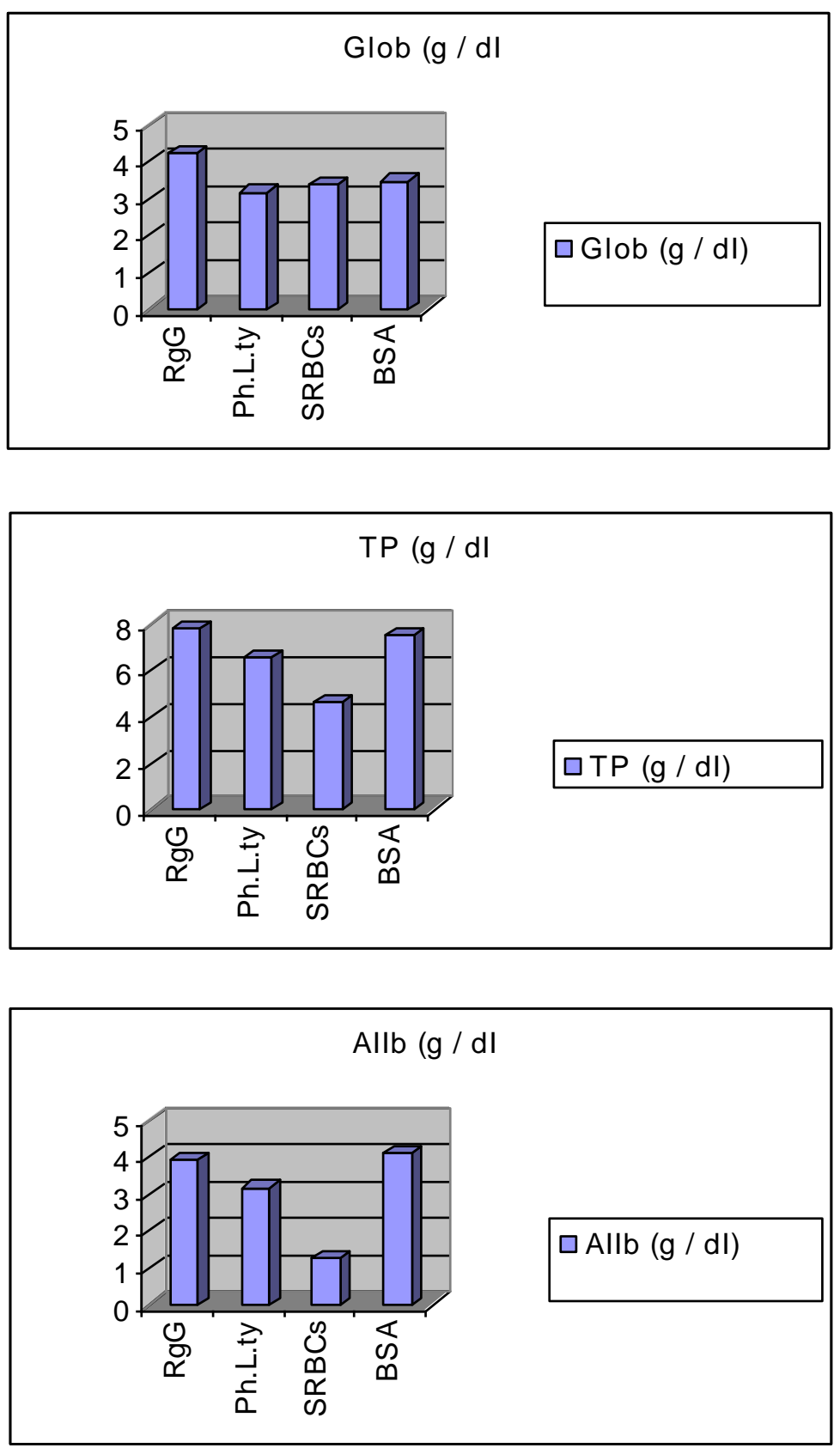

Fig. (3): Effect of RgG, ph.L. ty, SEBCs and BSA on total protein, albumin, globulin and A / G ratio. 


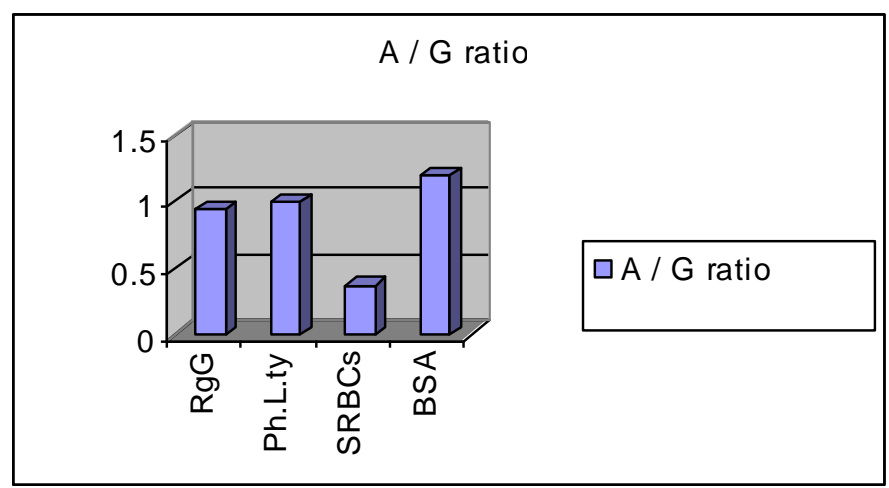

Fig. (4 - a): Effect of RgG,ph.L. ty ,SEBCs and BSA on total immunoglobulin.

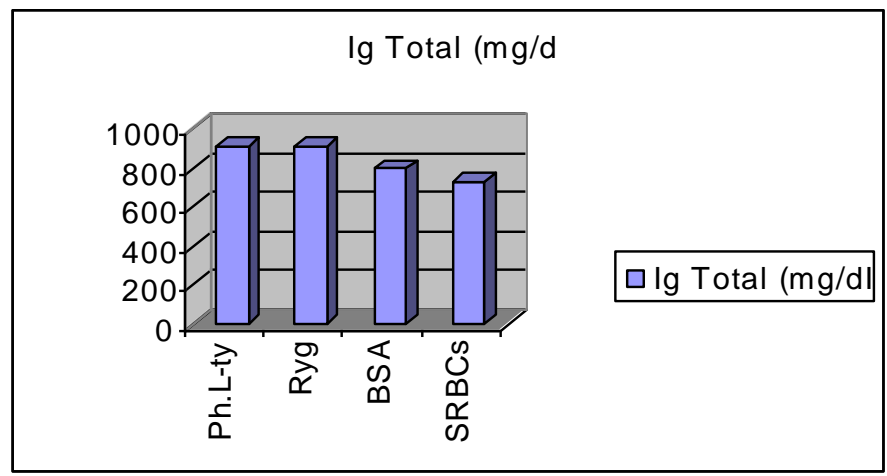

Fig (4 - b): Effect of $\operatorname{RgG}$, ph.L. ty, SEBCs and BSA on IgA, IgM and IgM.

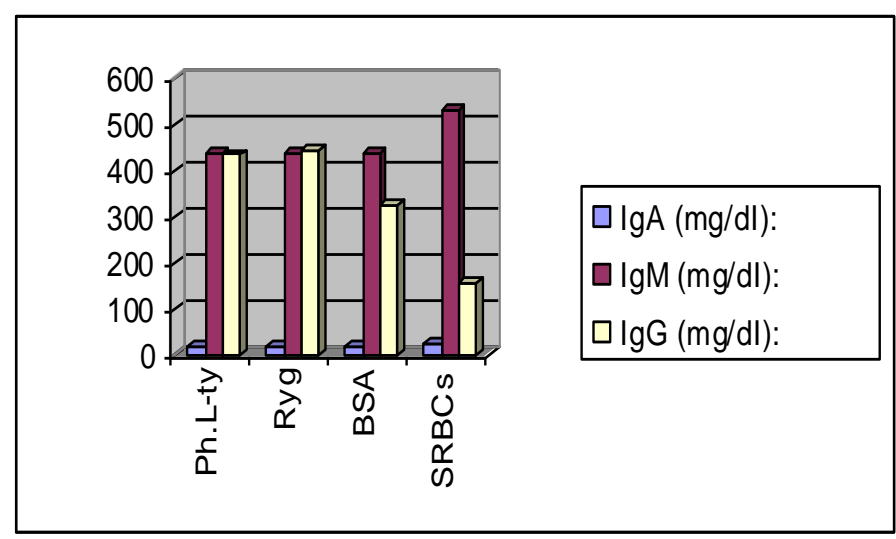

$\overline{\overline{\text { Kafr El-Sheikh Vet. Med. J. Vol. } 4 \text { No. } 1 \text { (2006) }}}$ 


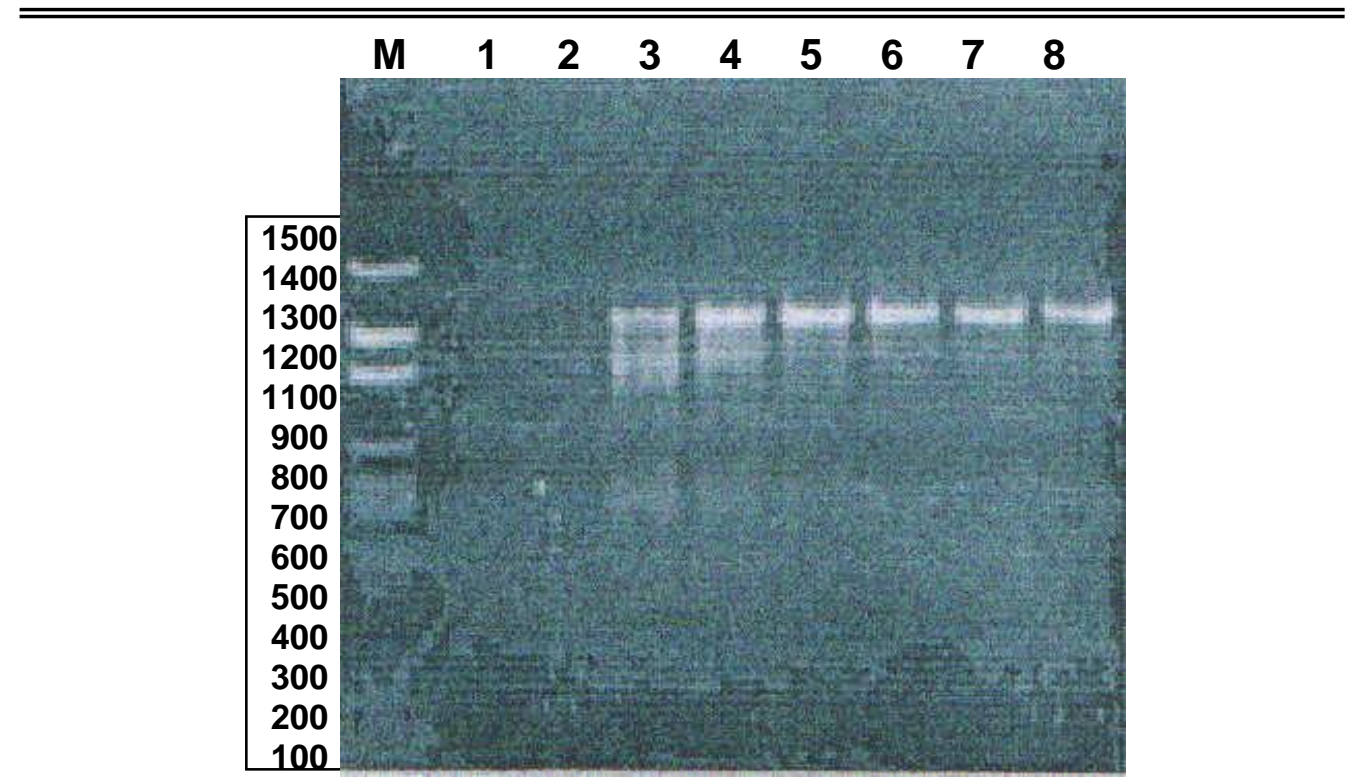

Fig. (5): DNA PCR- Products before rabbis immunization by SRBCs, ph.L.ty, and BSA antigen, (M) Marker molecular weight ranged from 1001500 base.

$\begin{array}{lllllllllll}M & \text { L1 } & \text { L2 } & \text { L3 } & \text { L4 } & \text { L5 } & \text { L6 } & \text { L7 } & \text { L8 } & \text { L9 } & \text { L10 }\end{array}$

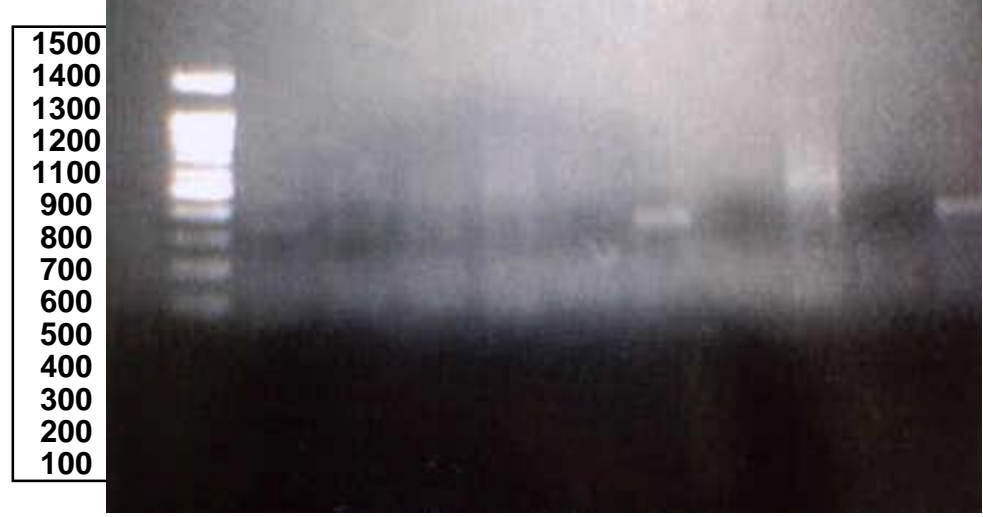

Fig. (6): DNA Marker (M) Molecular weight ranged from 100-1500 base pair (bp) and lane (L) L2 of SRBCs samples was faint and had low molecular weight (180 bp), L4 for ph.L.ty was very faint (240), L8 for $\mathrm{RgG}(550 \mathrm{bp})$, and L10 for BSA (440bp).

Kafr El-Sheikh Vet. Med. J. Vol. 4 No. 1 (2006) 


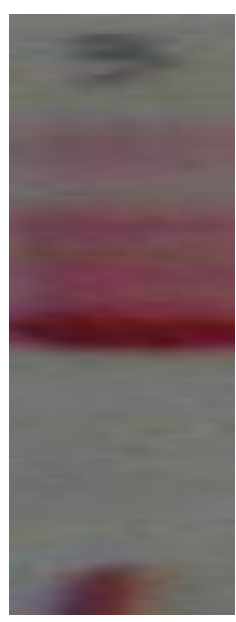

RgG

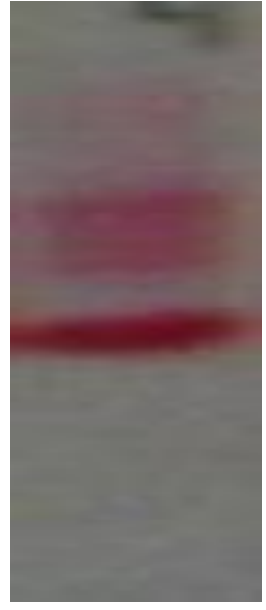

BSA

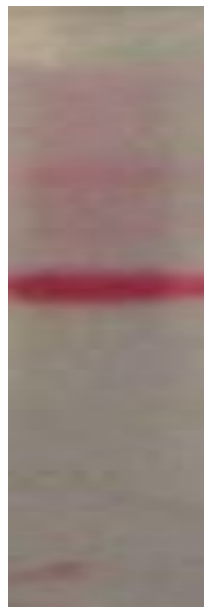

ph.L .ty

Fig. (7)

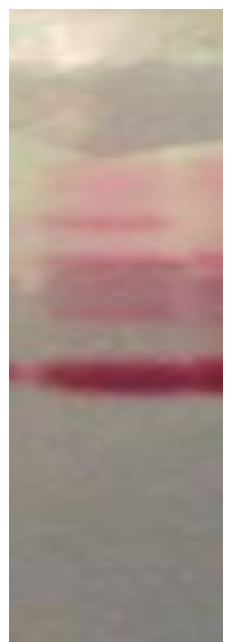

SRBCs

Fig. (8)

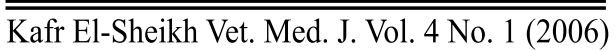




\section{REFERENCES}

- Abou- Elewa .Eman. M. A.(2004): Selection for general immune response and its relation to some economical traits in chickens . M.Sc. Thesis, Fac. of Agric., Minufia univ. Egypt.

- Biozzi, G; G. Stiffel, D; D.Maton and Y. Bouthillier, (1975): Selection of line of mice with high and low antibody responses to complex immunogens -Immunogenetics and Immuno deficiency.B. Benacerral, ed. University.park press, Baltimor,MD. Pp,177-227.

- Candace, R. Winstead, Shi - Kang Zahai, Periannan. S, and Katherine .L. Knight (1999): Antigen induced somatic diversification of rabbit $\mathrm{IgH}$ genes: Gene conversion and point mutation. J. of Immunol. 162: 66602 - 6612.

- Choi, K. H., S. K. Mahes waran, L. J. Felicle and T. W. Mditor, (1991): Relationship between the iron regulated OMP and the OMP of in vivo growth .P.multocida. Vet. Microbial ., $28: 75-92$.

- Coffn,D.L. (1955): Manual of Veterinary Clinical pathology, Corneal University Press, New York, $3^{\text {rd }}$ edition.

- Doumas, B. T.; Waston, W. A. and Biggs, H. G. (1971): Albumin standards and the measurement of plasma Albumin with Bromocresol green. Clin chem . Acta ,31: 87 - 92.

- Duncan, D. B. (1955): Multiple range and multiple F-test. Biometrics, 11:1-42.

- Ferreira - VCA ; Reis - M H ; Gennari - M ; Siqueria-M ; Mouton - D; Bioizzi. $G$ (1986): Genetics of antibody responsiveness to bovine serum albumin and rabbit gamma globulin.1- Genetic analysis of high and low responder lines of mice produced by selective breeding. J. of. Experimental - and Clinucal Immunogenetics .3 :3, 162 -171,15 ref. 
- Fusheng J.ZZhu . Qi ; Chen - FS; Zhou-Q.Nahrung (2002): Comprative study on the charachterization of antisera of anti - aflato-xinB1 from rabbit and laying hen. Vet.Immunol. Immunopathool.46: 6, $430-436$.

- Gottlieb, C.F., E.H., Perkins and Makinodan (1971): Genetic regulation of the thymus dependent humoral immune response in Leukemia Prone AKR $\left(\mathrm{H}-2^{\mathrm{k}}\right)$ and non Leukemic C3H $(\mathrm{H}-$ $\left.2^{\mathrm{k}}\right)$ mice. J. of Immunol.. 109: 974- 981 .

- Grimminger.P.,(1986): Lipid Metapolism in "Avian Physioligy" edited by P.D.Starkie $4^{\text {th }}$ ed .Springer verloge.New York, USA.

- Helal, A . D . and Mousa, H . M (2005): Chromosomal aberrations induced by glyphosate iso propylamine herbicide and trials for determining its toxicity using some chemical inactivitors and antioxidant . Vet .Med. J., Giza . Vol . 53 : 169 - 187.

- Helcio. C. Passos ; Maria Siqueira ; Moema H . Reis, Vera C. Annaes Ferreira ; Olya M. Ibens ; Osvaldo A, Santanna and Guido Biozzi (1977):Genetic control of immune response to protein antigens. 1. Two way selective breeding of mice for quantitive antibody responsiveness to bovine serum albumin and rabbit gamma - globulin . The Journal of Immunopathology .119: $1439-1444$.

- Higgens - DA; and Gatrill - AJ, (1984): A Comparison of the antibody response of badgers ( Males males ) and rabbits (Oryctolagus Cunniculus) to some common antigens. J. of. International - Archives - of - Allergy - and Applied Immunol. $75: 3,219-226 ; 38$ ref .

- Hirai. N; Xun-S; Onuna .M (1994): Alteration of immune responses of rabbits infected with bovine immunodeficiency - 
like virus. J. of. Microbiology and Immunology. 38 : 12, 943 950.

- Jones, R.; Mann,T.and Sherins, $R$.(1979): Peroxidative breakdown of phospholipids in human spermatozoa, spermicidal, properties of fatty acid peroxides, and protective action of seminal plasma. J. Fertility and Sterility.31: 531 537.

- Kabat, E.A., and M.M. Mayer. (1961): In Kabat and Mayer' sexperimental Immunochemistry. Charles C. Thomas, Springfield, III.P. 871.

- Klipper; David Sklan, and Aharon Freidman (2000): Immune response of chickens to dietary protein antigen 1 . Induction of systemic and intestinal immune responses following oral administration of soluble proteins in the absence of Adjuvant. J. of. Vet. Immunol. and Immunopathool.74 : 209 - 223.

- Kruger. J, and Gershon. K. (1972): DNA synthetic of thymocytes to a variety of antigens. J. of. Immunol. 108 : 581 585 .

- Merk, E. (1974): Clinical Laboratory, 11 Ed. of Microchemical Inve-stigation Methods . Darmstadt, Federal Repuplic Germany.

- Moosmann, B. and Behl, C. (2002): Secretory peptide hormones arc biochemical antioxidants, structure-activity relationship. Mol. Pharm-acol Proc. Soc. Exp. Biol. Mcd., 177(1): 42-46.

- Munro, H. N (1970): Mammalian protein metabolism, Vol .IV.New York; Academic Press.

- Naz. R. K. (1996): Application of sperm Antigen in Immunocontrace-ption. Frontiers in Bioscience 1, e 87-95 
.New Zealand White rabbits. M. Sc. Thesis, Ain Shams University, Egypt.

- Omara M. E.; Abd El-Ghani. A; Rawia, H. Sadek and Safia T.Kandil. (2002): Autogenous vaccination of meat type rabbit under Egyptian conditions for controlling rabbit Pasteurelosis using propion-ibacterium and lipo polysaccharides immunostimulant. $3^{\text {rd }}$ Sci.Con. on rabbit production in hot climates, 8 - 11 Oct.: $449-459$.

- Paramentier H. K; R. Siemonsa , and M. G.B. Nieuland (1994): Immune response to bovine serum albumin in chicken lines divergently selected for antibodies response to sheep red blood cells . Poultry Sci.73 : 825 - 835 .

- Passos, H. C; Siqueria, M. M. H. Reis; V. C. Annes Ferreira; O.M Ibanezo; Sant Anna, O. M and Biozzi, G (1977 ): Genetic control of immune response to protein antigens 1- Two way selective breeding of mice for quantitative antibody responsiveness to bovine serum albumin and rabbit gamma globulin. J . of Immunl, 119 : 1439 - 1444.

- Perkins, E.H and T. Makinodan (1972): Genetic control immune response : Description of genetic control of the immune response at the level of proliferation. 111: $815-825$.

- Pushpa, S.K.; Kalra, S.P., Krulich, L.; Fawcett, C.P. and McCann, S.M. (1972): Involvement of norepinephrinc in transmission of the stimulatory influence of progesterone on gonadotropin release. Endoc-rinol., 90: 1168-1 176.

- Rothberg, R M. ; and Peri, B .A (1986):Immunoloregulation of the young by mucosal immunization of the maternal animal. International-Convocation-on-Immunology. 51 : (1) 49 53;.18. ref. 
- Rudikoff, S; and M. Potter .(1980): Allelic forms of the immunoglob-ulin heavy chain variable region. The Journal of Immunology, Vol. 124, Issue 5 : 2089 - 2092.

- Sant, Anna - O. A.; Ibenez, O.M ; Ferreira - VCA; Gennari - M; Mouton .D.(1983): Inverse modification of antibodies responsiveness to RGG in lines of mice selected for high or low responses to somatic antigen of salmonella. $J$. of. Immunogenetics. $18: 4,359-364,11$ ref.

- Schalm, W . O (1965): Veterinary Haematology . 2nd Ed .,Springer

- Shaker, Y . M. ( 997): Some physiological aspects of growing female Snedecor., G.W and Cochran (1967). Stastical methods $2^{\text {nd }}$ Ed. Iowa univ. presst. Amess, Iwa..

- SPSS, (1993): Statistical Package for Social Science, SPSS for Windows . Computer Program, version, 8.

- Vaermans, J . P ; J.F. Heremans (1971): The IgA system of the Guinea pig . the Journal of Immunol . $108: 637-646$.

- Vanoverveld, F.W., Haenem, G.R., Rhamrev, J., en, J.P. and Bast, A. (2000): Tyrosine as impo tribulor to the antioxidanl capacity of semim Chcm. Biol. Interact. 127(2): 151-161. Verlg, New York Heid-elberg Berlin.

- Walter and Zipper .(1958): The metabolism of some antigen antibody complexes in the rabbit .Journal of Immunology 82 : 12-18 .

- Wilkie Bruce and Mallard Bonnie, (1999): Selection for high immune response:an alternative approach to animal health maintenance. The Journal of Immunopathology .72 : 231 235. 
- Wurtman, RJ (1982): Nutritions that modify brain functions.

Sci. Amm. 246: 50-59.

التأثثر ات المناعية لبعض المستضدات و الاستجابة الحسية للحامض النووي على ذكور الأر انب

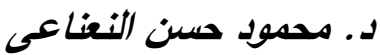

استخدم فى البحث 72 أرنب ذكر كاليفورينـا تم اختبارهم عشوائياً عند عمر 5.5 شـهور ثم تقسيمهم اللى أربعة مجاميع منسـاوية " كل مجموعة 18 أرنب"على حسب نتائج التحصين حيث تم تحصينهم أربعة تحصينات بأربعة مستضدات : كرات الدم الحمراء للفم ، مصل البيومين البقر ، وجاما جلوبيولين الأرانب ، فوسفو -ل تيروزين وذلك للمجاميع 1، 2، 3، 4 على التوالى. حيث تم حقن كل مجموعة اربعة مرات، بالمستضدات والمادة المساعدة الخاصة بها : المجموعة (1) تم حقنها بالمستضد و فرندز الكامل ، المجموعة (2) تم حقنها بالمستضد و فرندز الغير كامل والمجموعة (3) تم حقنها

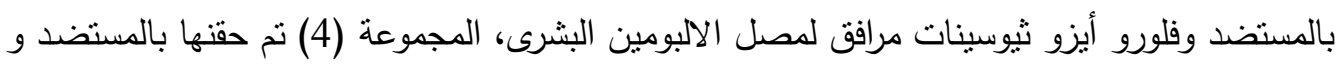
5 - أيودو - 2 - دى أوكسى يوريدين. تم حقن الارانب تحت الجلد فى التحصين الاول وبعد 28 يوم تم التحصين الثانى فى الوريد وايضا بعد 28 يوم أخرى تم التحصين الثالث فى وخذ القدم. ثم بعد 15 يوم نم التحصين الرابع فى الوريد ـ أخذت عينات الدم من وريد الاذن الطرفى على فترات بعد 7 ، 14 ، 21 يوم من التحصين الاول والثانى وذلك لتقدير الاختبارات المصلية (الاجسام المضادة ومعايرتها) ثم صنفت الارانب الى مجموعات عالية الاستجابة ومنخفضـة الاستجابة وتم استبعاد الارانب المنخفضة الاستجابة المناعية. وفى نهاية التجربة تم ذبح الارانب وأخذت عينات الدم لتقدير الصفات الفسيولوجية

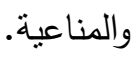

وكذلك تم دراسـة مدى حساسية الـ DNA فى أنسـة الخلايـا التيمويثة وتكبير الـ DNA

بجهاز الـ PCR ونم استخدام بريمر خاص " كاشف" لدراسة تتابع الامينوجلوبيولين فى السلسلة النقيلة (IgH). أوضحت النتائج المصلية انة وجد فرق معنوى على مستوى (0.05) بين المجاميع فكانت

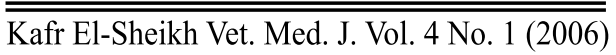


المجموعة (1) الاعلى فى الاستجابة وكانت المجموعة (4) اقل المجاميع استجابة. أوضحت دراسة

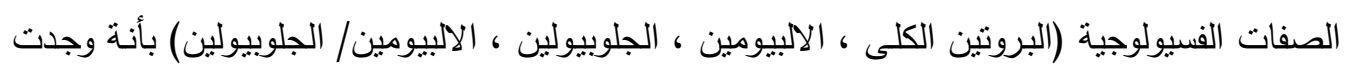
فروق معنوية على مستوى 0.05 بين المجاميع وكانت المجموعة (3) ذات القيمة العالية وكانت أقلهح

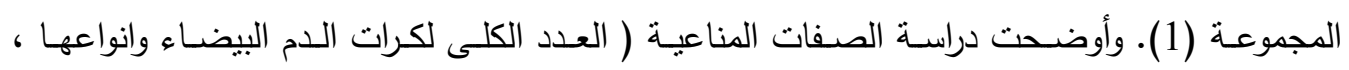
الامينوجلو بيولين وانواعه وهى ألفا وميو وجامـا) وجدت فروق معنوية عالبـة على مسنوى 0.01 بين المجاميع. بالنسبة للعدد الكلى لكرات الدم البيضاء وانواعها وكانت المجموعة (1) و (2) الاعلى فى القيم.وبالنسبة لنتائج الامينوجلو بيولين (Ig) كانت المجموعة (3) هى الاعلى قيمة فى الامينوجلو بيولين الكلى ثم يليها المجموعة (4) وكانت أقلهم المجموعة (1). بينما المجموعة (2) كانت ذات قيمة وسطية وكانت الفروق معنويـة بين المجاميع على مسنوى 0.05 .أمـا بالنسبة لانواع الامينوجلو بيولين ( ألفا ، ميو ، جاما) وجدت فروق معنوى بين المجاميع على مستوى 0.05 وكانت أعلى قيمة للالفا فى المجموعة (4) وأقلهم فى المجموعة (1). بينما أعلى قيمة فى الميو كانت فى الدجمعة (1). أما بالنسبة للجاما كانت المجموعة (3) الاعلى قيمة عن باقى المجاميع. بالنسبة لتكبير الحـامض النووى DNA تلاحظ وجود اختلاف بين تكوين الحزم الخاصـة بالحامض راجع لتأثثر المستضدات المختلفة ومدى تأثيرها على الصفات الخاصة بالامينوجلو بيولين ذات السلسلة الثقيلة (IgH). بالاشارة الى صفات السائل المنوى قد إتضح وجود فروق عالية معنوية على مستوى 0.01 بين المجاميع وكان السائل المنوى الخاص بالمجموعة (4) أقلهم فى عدد الحيوانات المنوية الميتة والثاذة وأعلاهم فى قيمة الحيوية عن باقى المجاميع.

نستتنج من ذلك ان مادة فوسفو ـل - تيروزين لها القدرة على تنبية الحامض النووى واحداث استجابة مناعية علاوة على زيادة الخصوبة فى ذكور الارانب. 